\title{
The Impact of Capital Structure on Profitability of Egyptian MSMEs in the Period From 2016 to 2019
}

\author{
Eslam Saadallah (Corresponding author) \\ Arab Academy for Science, Technology and Maritime Transport, Egypt \\ E-mail: eslamsaadallah@gmail.com
}

Amr Youssef

Arab Academy for Science, Technology and Maritime Transport, Egypt

Aiman Ragab

Arab Academy for Science, Technology and Maritime Transport, Egypt

Ashraf Salah

Arab Academy for Science, Technology and Maritime Transport, Egypt

Received: February 6, $2021 \quad$ Accepted: February 20, $2021 \quad$ Published: March 11, 2021

doi: 10.5296/ijafr.v11i1.18286 URL: https://doi.org/10.5296/ijafr.v11i1.18286

\begin{abstract}
MSMEs are essential for economic development for they act as employment engines, aid poverty alleviation and amplify broad-based economic growth. This research focuses on the impact of capital structure on Egyptian MSMEs profitability.

This dissertation utilizes a quantitative approach in research. Secondary data is used in this study via using the annual reports of 360 MSMEs in Egypt in the period from 2016 to 2019 (120 micro enterprises, 120 small enterprises and 120 medium enterprises). Data was collected for the research variables: capital structure represents the independent variable; it is measured by debt ratio and equity ratio. Profitability of MSMEs represents the dependent variable, it is measured by return on assets, return on equity and net profit margin. Firm size and firm age represent the control variables.
\end{abstract}

As far as micro samples and small samples were concerned, it was found that there was a 
significant negative correlation between Debt ratio and ROE, ROA and NPM. However, it was found that there was a highly significant positive correlation between Equity ratio and ROE, ROA and NPM. This result tends to support the pecking order theory of micro and small businesses capital structure in Egypt which postulates that internal sources of financing are better than external sources in the case of high interest rate due to the high costs of financing. In regards to medium firms, it was found that there was a positive significant correlation between debt ratio and ROE, ROA and NPM. On the other hand, it was found that there was a negative significant correlation between Equity ratio and ROE, ROA and NPM. This result tends to support the tradeoff theory of Medium businesses capital structure in Egypt. Concerning firm age, it was found that smaller aged firms have better rates of profitability than large aged ones. Regarding firm size, it was found that smaller sized firms have better rates of profitability than large sized ones.

Keywords: Debt ratio, Equity ratio, Profitability, Return on assets, Return on equity, Net profit margins, SMEs, MSMEs

\section{Introduction}

MSMEs have become one of the key instruments to aid in the economic enhancement and the progression of developing countries. MSMEs contribute to employment creation and productivity improvement. Statistics in Egypt show that MSMEs provide 40-80\% of total job opportunities and represent $90 \%$ of total companies in the majority of economies (Elasrag, 2012). Access to credit is important for the growth of MSMEs. Thus, policy makers ought to pursue financial sector policies to propel financial intermediaries in order to provide more credit to small businesses. However, access to credit still remains a hurdle to small businesses especially those in developing economies. This issue continues to dominate discussions within both business circles and governments.

MSMEs generally present capital structures that are poorly planned, often do not use the most appropriate structures for maximizing their financial performances. The capital structure is the combination of debt and equity that a firm uses to finance its business. The impact of capital structure on the value and performance of the company is still an issue that, in the theory of corporate finance and in the literature of finance, has yet not been solved.

The capital structure has attracted an intense debate in the field of finance especially during recent years. In spite of the extensive empirical analysis of the decisions of finance in big firms, the empirical research of the capital structure of MSMEs has been relatively recent. The size of firms and the age of firms seem to be important factors determining the capital structure and its impact on profitability. Firms choose the debt and equity mix by balancing the costs and benefits. Managers who are competent attempt to identify the appropriate mix of debt and equity in an effort to minimize the firm cost of finance, maximize profitability and improve the competitive advantage.

There are various sources of funding for MSMEs, but MSMEs owners lack the necessary awareness about the optimal capital structure and the convenient source of finance. There are many theories of capital structure such as: Trade-off theory: It is an extension of the MM theory 


\section{Mll Macrothink}

International Journal of Accounting and Financial Reporting

ISSN 2162-3082

2021, Vol. 11, No. 1

developed by Miller and Modigliani. The theory proposes that a firm's optimal capital structure should include the tradeoff among the influences of firms and personal taxes, agency costs and bankruptcy costs, etc. Tradeoff theory expects that corporations choose levels of debt in order to achieve equilibrium among the benefits from the interest tax shield with the costs related to a future financial distress.

Moreover, Pecking Order theory states that firms have two main sources to fund their financial needs; which are internal and external financing. The theory claims that firms prefer to first use internal financing; such as excess liquid assets or retained earnings, then external financing. If internal financing is not enough to fund investment, firms may or may not obtain external financing, and if they do, in order to minimize additional costs of asymmetric information, the managers opt for choosing between the different sources of external financing. Firms prefer to use debt leverage first, issuance of preferred stock second and finally issuance of common stock (Nasser 2016).

\section{Research Objectives}

The overall objective of this research is to measure the impact of capital structure on the profitability of Egyptian MSMEs. In addition, this study explains the policies and mechanisms that are needed to support MSMEs, improve their profitability and clarify the optimal capital structure of Egyptian MSMEs, where MSMEs suffer from many problems. The literature review revealed that there are different views on the impact of capital structure on the profitability of Egyptian MSMEs. So, there are four objectives which are required to be achieved:

- Measuring the impact of capital structure on the profitability of Egyptian MSMEs.

- Assessing the impact of firm size and firm age on the profitability of Egyptian MSMEs.

- Clarifying the optimal capital structure of Egyptian MSMEs.

- Explaining the policies and mechanisms to support MSMEs and improve their profitability.

\section{Literature Review}

Salawu (2009) investigated the annual financial statements of 50 firms from 1990 to 2004 in Nigeria, in which a positive correlation between short-term debt and equity with profitability could be observed. Furthermore, the results indicate a negative association between debt ratio and profitability. The research suggests that companies should implement an effective and efficient credit policy, which will improve the performance level of the turnover and growth.

Safari et al., (2013) investigated the annual financial statements of 85 firms from 2006 to 2011 in Tehran, in which the ROE and Tobin's Q are significantly and positively associated with capital structure, while a negative relation between capital structure (debt ratio) and (ROA, EPS) could be clearly seen. Moreover, Luka and Badmus (2014) studied the annual reports of 70 firms from 2000 to 2009 in Nigeria, in which the debt ratio is negatively related with profitability and this finding indicates a consistency with prior empirical studies, and provides 
evidence against the agency cost theory.

Nasser, (2016) studied the annual financial statements of 136 Turkish companies listed in Istanbul where the existence of a negative significant relationship between debt ratio and firm performance was observed. Moreover, Naim, (2016) used 30 companies from 2005 to 2014 in which interest coverage had a positive significant impact on ROA, ROE where debt to equity has positive significant impact on ROE but negative significant impact on ROA. The study concluded that the higher the value of debt, the higher the tax benefits will be (tax shield).

Emin, (2016) studied the annual financial statements of 110 Turkish firms from 2003 to 2015 where it was shown that short-term debt and long-term debt have a negative effect on return on equity and return on assets. This indicates that the cost of both short-term debt and long-term debt decreases the firm performance significantly. Moreover, Ashraf et al., (2017) investigated the annual financial statements of 18 Pakistani firms from 2006 to 2015 in which debt ratio and long-term debt have significantly negative relationships with (ROA) and (ROE), while short term debt had a significantly positive relationship with ROA and ROE.

Sadiq and Sher (2016) studied the annual financial statements of 19 firms from 2006 to 2012 in Pakistan, where debts to equity have a negative effect on return on equity and return on assets and net profit margin. Furthermore, Sarker et al., (2019) investigated the annual financial statements of 50 firms from 2013 to 2017 in Bangladesh, in which the debt ratio and equity ratio have a significant positive impact but debt to equity ratio has a significant negative impact on ROA. This study also reveals that equity ratio has a significant positive impact but debt to equity ratio has a significant negative impact on ROE.

Abrar and Javaid (2016) studied the annual financial statements of 70 micro firms from 2004 to 2010 in Pakistan, in which an increased risk leads to decrease in profitability, debt ratio has significantly positive associations with profitability, and an increase in the deposits leads to an increase in the firm's profitability Moreover, Singh (2018), investigated the annual financial statements of 172 Taiwan firms from 2011 to 2016, where a weak correlation of strength between capital structure and firm profitability could be observed.

Additionally, Azizi and Taher (2017) studied the annual reports of 81 firms from 2007 to 2016 in Iraq, where there was a non-significant negative relationship between ROA with financial leverage and a significant positive relationship with tangible assets, firm Size and duration. Also, the organizations should pay attention to the variety of financing sources, which achieves a greater return.

Based on prior studies that were reviewed, there are different points of view regarding the impact of capital structure on MSMEs profitability. According to the literature review, the current study plans to analyze the impact of capital structure on Egyptian MSMEs profitability from 2016 to 2019 . Thus, this study fills in the academic gap based on the literature review above; this study uses debt ratio, equity ratio, return on assets, return on equity and net profit margin in the assessment. 


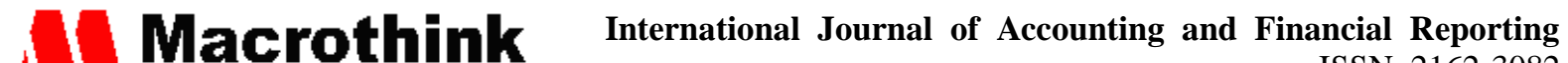 Institute"'

\section{Theoretical Framework}

\subsection{Capital Structure Theories}

Modigliani and Miller (MM) theory $(1958,1963)$ proposed that the value of a firm is independent from its capital structure under the assumptions of no taxes, no transaction costs, no bankruptcy costs, symmetric information and perfect markets. Such a proposition is also known as the Irrelevance Theory of capital structure. Following their original propositions, Modigliani and Miller made a correction about the relation between capital structure and firm value with taxes in which the cost of capital has an effect on capital structure, and consequently an effect on firm value with taking taxes as assumption into consideration, which postulates that borrowing gives tax advantage (tax shields), which in turn reduces the cost of debt and then maximize the firm performance (Emin, 2016).

Trade-off theory: is an extension of the MM theory developed by Miller $(1958,1963)$. This theory proposes that the firm's optimal capital structure should be inclusive of the tradeoff among the influences of firms and personal taxes, agency costs and bankruptcy costs, etc. Tradeoff theory expects that corporations choose levels of debt in order to achieve a balance among the benefits from the interest tax shield with the costs related to a possible future financial distress.

Pecking order theory states that firms have two main sources to fund their financial needs which are internal and external financing. The theory claims that firms prefer to first use internal financing such as excess liquid assets or retained earnings then external finance. If internal financing is not sufficient to fund investment, firms may or may not obtain external financing, and if they do, in order to minimize additional costs of asymmetric information, managers resort to choosing between the different sources of external financing, firms prefer to first use debt leverage, issuance of preferred stock second, and finally issuance of common stock (Nasser, 2016).

The agency theory: provided by Jensen and Meckling (1976) discusses the conflict of interest between shareholders and managers of firms, this conflict stems from the differences in behavior or decisions by pointing out that the parties often have different goals, and different tolerance approaches toward risk. In this case, the managers who are responsible for guiding the firm are keen on achieving their personal goals rather than maximizing benefits to the shareholders. Hence, the main conflict that shareholders face is to ensure that managers do not invest the free cash flow in unprofitable projects. From another angle, increasing the debt-to-equity ratio would assist firms to make sure that managers are running the firm more efficiently (Nasser 2016).

\subsection{Experiences of MSMEs in Egypt}

The Egyptian economy is one of the most diverse economies in the Middle East, comprising profound agriculture, tourism, manufacturing and services sectors. Owing to recent structural reform, the Egyptian economy is achieving high growth rates. A quite attractive investment climate has evolved due to positive developments in a number of diverse sectors such as transportation, infrastructure, communication, skilled labor, and energy. Furthermore, there has 
been prominent attention directed at the founding of modern industrial cities, free zones, banking reforms and stock markets' enhancement.

On December 16, 2008, the Central Bank of Egypt issued a decision. (No. 2408) entailing that banks are exempted from the $14 \%$ deposit reserve ratio since they provide credit facilitations to SMEs. This decision applies to companies which have sales from 1 million EGP to 20 million EGP and a capital of 250 thousand EGP to 5 million EGP. Institutions determine the size of the company's business by submitting audited financial statements from the auditor. (www.cbe.eg).

Towards the end of 2014, the Social Fund for Development (SFD) launched an initiative to support small businesses and micro businesses at an interest rate of $10 \%$ (decline simple rate). This was applied to more than 10 banks operating in Egypt. The mid corridor rate at this time was about 10.25\%; and the mid corridor rate in April 2018 was about $18.25 \%$ (www.sfdegypt.org).

On December 3, 2015, the Central Bank of Egypt issued a decision that defined medium companies; where it indicated that medium companies were to hold capital ranges from 5 million EGP to 10 million EGP for industrial companies and from 3 million EGP to 5 million EGP for other companies. Manpower was to range from 10 to 200 workers and sales from 20 million to 100 million EGP. Concerning small companies, the capital was to range from 50,000 EGP to 5 million EGP for industrial companies, and from 3 million to 5 million for other companies.

Manpower was to range from 10 to 200 workers. Sales were to range from 10 million EGP to 20 million EGP. In very small companies, the capital and manpower were the same. However, sales range from 1 million EGP to 10 million EGP. The Central Bank of Egypt initiative issued on December 16, 2008 included only small and very small companies. It canceled the element related to the presentation of financial statements approved by the auditor; which determines the size of the business.

On December 6, 2015, the Central Bank of Egypt issued a decision that entailed increasing the loans and facilitations' portfolio granted to SMEs by at least $20 \%$ of the Bank's total portfolio within 4 years from the date of issuance of these instructions; allocating LE 200 billion to finance small projects within 4 years (164 billion EGP was achieved until December 2019). The lending rate for small businesses (sales range from 1 million EGP to 50 million EGP) was not to exceed 5\% (decline simple rate). It did not allow the approval of new credit facilities to repay existing credit facilities in an effort to take advantage of the new pricing.

On February 22, 2016 the Central Bank of Egypt issued a decision that employed initiative to support medium industrial business at an interest rate of $7 \%$ to finance fixed assets with a maximum of 40 million pounds per company. On February 2, 2017 a decision was issued by the Central Bank of Egypt stating a new definition of MSMEs as follows: Medium companies, capital ranging from 5 million EGP to 15 million EGP; industrial companies ranging from 3 million EGP to 5 million EGP, workforce ranges from 10 to 200 workers; and sales range from 50 million pounds to 200 million pounds. For small companies, capital ranges from 50 


\section{$\Lambda$ Macrothink}

International Journal of Accounting and Financial Reporting

ISSN 2162-3082

2021, Vol. 11, No. 1

thousand EGP to 5 million, and ranges less than 3 million EGP for industrial companies and other companies, work force ranges from 10 to 200 workers, and sales range from 1 million EGP to 50 million EGP micro companies, sales range less than 1 million pounds. (www.cbe.eg).

On April 24, 2017, the Egyptian Prime Minister issued a decree in an effort to establish the Development Authority of Small and Medium Enterprises. The decree added to the Social Fund for Development to include: training programs, financing programs, investment ideas, and investment opportunities.

On May, 3, 2017 the Central Bank of Egypt issued another decree in which initiative was to be employed to support medium industrial business at an interest rate of $12 \%$ to finance working capital.

In addition to the aforementioned, the Central Bank of Egypt (CBE) supports the Credit Guarantee Company. Said company decided towards the end of 2017 to increase credit insurance policies in return for granting credit to small companies by up to 15 million EGP instead of 2 million EGP that are owned by public sector banks. Over the course of July 2017, the Central Bank of Egypt decided that agro-processing, animal feed, fisheries and dairy projects with sales ranging from 250,000 to 50 million EGP have the right to benefit from the $5 \%$ initiative (www.cgcegypt.com). Finally, the Central Bank decided on January 9, 2019 to limit the initiative to industrial, health and contracting projects only.

In May 2019, the Small and Medium Enterprises Development Authority launched a new initiative to support small and micro businesses. It declared an interest rate of $13 \%$ (decline simple rate) through more than 10 banks operating in Egypt. The mid corridor rate at this time was about 16.25\% (www.msme.eg). On December 12,2019 the Central Bank of Egypt deployed an initiative to support industrial and agricultural businesses; for medium-sized enterprises and large corporate companies with an interest rate of $8 \%$ in an effort to finance fixed assets and working capital.

\subsection{India MSMEs Experiences}

Developments in information technologies, which can be used as a medium for improving SMEs, logically led India's government to be keenly interested in building information systems for SMEs. Thereby, promoting innovation and supporting entrepreneurs. (Todd and javalgi, 2007). In India, $11 \%$ of SMEs have a vision and strategy, and $15 \%$ have integrated information systems (kale et al 2010)

In India MSMEs and startups face a host of barriers. Inappropriate regulatory elements and legal bottlenecks have severely hampered productive entrepreneurial activities. Many Indian entrepreneurs still struggle with a culture that looks down on capitalism and is indifferent to hard work, improvement and innovations.

SMEs in India are playing an important role in the international marketplace and there is a strong relation between entrepreneurship and the degree of internationalization. It is then important to highlight that, as SMEs grow older, they will acquire greater knowledge and 


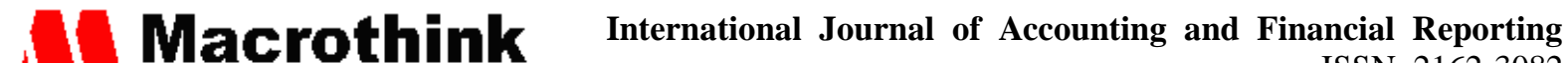 ISSN 2162-3082 2021, Vol. 11, No. 1}

information of how foreign markets operate. (Javalgi and Todd, 2011)

According to a research by, Jill et al., (2012) it was explained that small business growth intensity and family ownership are the only factors that act as predictors of small business growth plans, family business role conflict and age. Since MSMEs play a vital role in the Indian economy, the research recommended that Indian government ought to provide free training programs for MSMEs.

Many countries counted on MSMEs as central and main pivots of development until they became among the most powerful tools of socio-economic growth programs. They are considered among the most strategic elements regarding the growth processes in developed as well as developing countries (Zakaria et al., 2013).

In India, the market encompasses a wide spectrum of Indian economy from traditional manufacturing sectors (textile, ceramics, forging, handicrafts, etc.) to modern technology and knowledge-based sectors (IT, biotic, telecom, logistics, etc.). MSMEs have recently been the development drivers of the Indian economy. Thus, sustainable development of small business is critical to the overall economic growth of the country. The Indian economy, being one of the largest economies in the world as measured by the Purchasing Power Parity (PPP) with a GDP growth rate of about $7.2 \%$, makes it the third-biggest economy after China and the United States. The MSME sector contributes to almost $40 \%$ to the entire output of India, $35 \%$ of its industrial exports and occupies $90 \%$ of the industry. Furthermore, employment in the MSMEs sector in India increased to reach 732.24 people $(73,200 \mathrm{~mm}$ ) in 2010-2011 (Zakaria at al., 2013).

There are several challenges that are faced by the MSME sector in India. These challenges are similar to other developing countries, where for example, there is certainly a lack of financing, planning, marketing assistance and technology representing the main hurdles hindering SMEs from attaining success. Banking restructure in India has begun since 1969. An integrated system is followed by having a unique entity; for the Ministry of Micro, Small, Medium Enterprises, has taken on the responsibility of coordinating all programs in an effort to achieve the National agenda. The Reserve Bank of India directs trends to all banks to follow in terms of allocating $40 \%$ of bank financing to MSMEs annually. In case of not covering the allocated percentage, the Reserve Bank directs the remaining to finance one of the top priority sectors such as textiles and agriculture; with an interest rate that is never to exceed $4 \%$. Banks seek to provide training and advisory services, non-financial services, on a free of charge basis for entrepreneurs via consultancy institutions and specialized training centers (Zakaria at al., 2013).

The contribution of Micro-Small and Medium Enterprises is highly remarkable to the overall industrial economy of the country. Simultaneously: they are facing intense pressure and constraints to sustain their competitiveness in a globalized world. Micro-small and medium Enterprises in India suffer from low demand, and lack of sufficient funds (Jaskaran and singh 2014).

Finance for micro, small, and medium-sized enterprises in India has been a concern for all 


\section{Mll Macrothink}

International Journal of Accounting and Financial Reporting

ISSN 2162-3082

2021, Vol. 11, No. 1

stakeholders; including entrepreneurs, financial institutions, and government organizations. The study conducted by Sign and Wasadani(2016) found that the main challenges faced in the underutilization of formal sources were primarily concerned with the inadequacy of collateral assets, lack of financial awareness of entrepreneurs and sources of finance used across the various stages of the life cycle being largely limited to personal funds, family wealth, friends and money lenders. The major common challenges faced in regards to accessing finance by small businesses in the start-up stage were the lack of knowledge about banking finance, providing collateral or a guarantee, and high interest rates.

MSMES in India still suffer from the lack of funding, lack of awareness, lack of training and lack of competitiveness in spite of government efforts. The government directs all Banks to cover $40 \%$ of the financing to MSMEs annually. They finance a number of the priority sectors such as textiles and agriculture, with interest rates never exceeding 4\%. The government also provides training and advisory services, non-financial services, all free of charge.

In order to solve the dilemma of the Financing gap faced by SMEs in India; research suggests that borrowers and lenders ought to cooperate. SMEs must improve the quality of information required to banks and improve their financial management skills. Financial institutions have to develop the procedural aspects for financing SMEs. The government should try to reduce the cost of finance.(verma et al 2017). SMEs bribery is detrimental to accessing finance, high corruption increases difficulties for financial institutions so as to control credit risk, recover bank loans and lessen the profit of SMEs.(Locke et al 2020)

\subsection{Morocco MSMEs Experiences}

The SMEs sector occupies an important targeted position within the credit policies of Moroccan banking operators. For, minimizing the SMES' risk namely requires the implementation of the following procedures: the involvement of banks, which must develop relationships with SMEs, all the while providing them with the necessary advice and support. In terms of liabilities, it is important to search for new partners to fund, in utilization of the existing diversification of suppliers, so as to negotiate more advantageous payment terms. At the level of the assets, it should be noted that the consolidation of the investment of SMEs in the assets is allocated to production, as well as customer diversification in order to reduce negotiated recovery times. As far as the market is concerned, it is essential to highlight the need to reinforce the role of marketing as a tool for the loyalty of SMEs customers. (MOUDINE and El Khattab, 2016)

SMEs have been regarded as the most essential revitalizing components for developing and developed economies. The main issue facing SMEs is related to the lack of an international benchmark to define them; and this particular obstacle inhibits most researchers from making solid and valid comparisons between different countries. Before 2005, the definition of SMEs in morocco was solely based on the criterion of employees, then the Moroccan government set a new common definition that was based only on the turnover criterion as follows in elaboration: Micro enterprise companies were to be considered with a turnover of less than 3MDHS, Small enterprise companies were to be considered with a turnover ranging between 3 MDHS and 10 MDHS and Medium enterprise companies were to be considered with a 


\section{Mll Macrothink}

International Journal of Accounting and Financial Reporting

ISSN 2162-3082

2021, Vol. 11, No. 1

turnover between 10 MDHS and 175 MDHS7 (MOUHALLAB.1 and JIANGUO.2, 2016)

Undoubtedly, SMEs are considered the key elements to the development of an economy such as that of a country like Morocco. It is explicit that they first require funds to start their activity. However, SMEs in Morocco happen to face a series of difficulties related to financial needs on account of the traditional financial system being positioned against them. SMEs in Morocco are not only facing a lack of tools and support, but also an inability to produce the necessary information for conventional banks to assess their credit applications. (Housni et al 2017)

Financial systems in Morocco are in a position where the demand for credit far exceeds the supply, thereby resulting in banks being very selective with granting credit and demanding more guarantees. Morocco PME (The National Agency for the Promotion of MSMEs), was entrusted with the mandate to set MSME policies, implementation, monitoring and evaluation; so, the Central Fund of Guarantee was established in an effort to solve the issue of access to finance and cater to the financing needs of MSMEs. (Sessa et al 2017)

The Ministry of Industry in Morocco introduced two strategies for 2014-2020, respectively addressing the development of the country's industrial base and the marketing of the goods produced within the realms of domestic and foreign markets.

MSMEs are predominant in the Agriculture and Maritime Fishing sectors, therefore The Ministry of Agriculture and Maritime Fishing is responsible for the implementation of strategies in this sector such as: Plans for Agriculture foreseeing the creation of six agro poles, and developing the fisheries sector by means of ameliorating the tools and infrastructure. (Sessa et al 2017)

Moreover, risk sharing in Islamic banking had a significant impact on Moroccan SMEs'. Similarly, SMEs support had a significant effect on the profit of Islamic banks. Moroccan SMEs acknowledged the importance of Islamic financial instruments as they were compatible with their financial needs. Moroccan SMEs need to know about Islamic financial products, their structures, principles and functions. Religious beliefs do not have a significant negative influence on the attitude of Moroccan SMEs. (Ziky and Daouah, 2019) 


\section{Macrothink \\ International Journal of Accounting and Financial Reporting ISSN 2162-3082 2021, Vol. 11, No. 1}

\section{Research Methodology}

5.1 Research Framework

\section{Research Frame work}

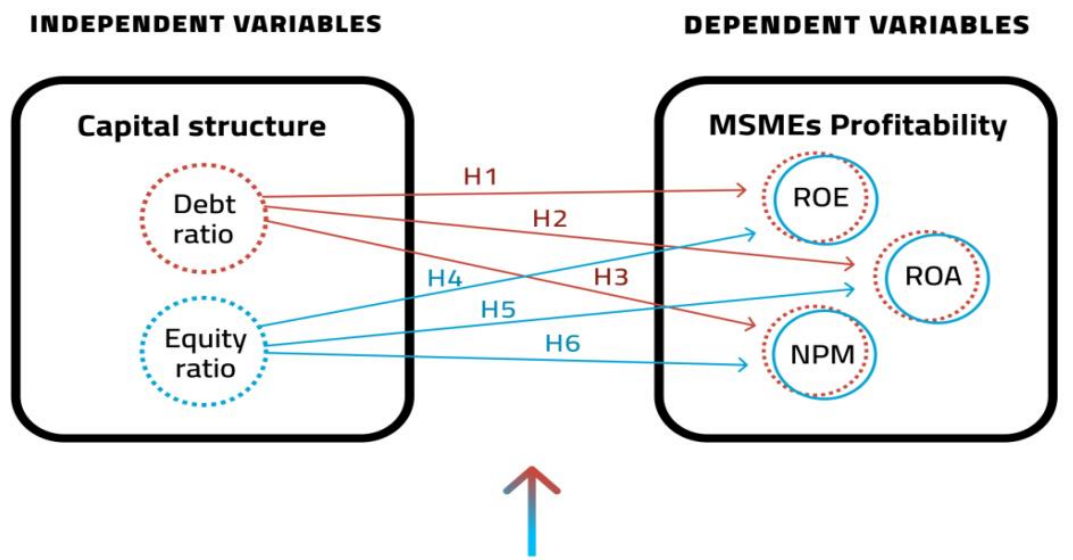

CONTROL VARIABLES

Firm age

Firm size

\subsection{Research Hypotheses}

Each proposed hypothesis is presented for the purpose of testing the impact of capital structure on the profitability of MSMEs in Egypt in the period from 2016 to 2019. The research hypotheses are stated as follows:

H1 Capital structure measured by debt ratio has a significantly negative impact on profitability (measured via ROA)

H2 Capital structure measured by debt ratio has a significantly negative impact on profitability (measured via ROE)

H3 Capital structure measured by debt ratio has a significantly negative impact on profitability (measured via NPM)

H4 Capital structure measured by equity ratio has a significantly positive impact on profitability (measured via ROA)

H5 Capital structure measured by equity ratio has a significantly positive impact on profitability (measured via ROE) 
H6 Capital structure measured by equity ratio has a significantly positive impact on profitability (measured via NPM)

H7 Firm age has a significantly positive impact on profitability of MSMEs

H8 Firm size has a significantly positive impact on profitability of MSMEs

\subsection{Research Variables Measurement}

\begin{tabular}{lll}
\hline Variable & Measurement & Equation \\
Capital & Debt ratio & $\begin{array}{l}\text { Debt ratio =total debt / total assets } \\
\text { (Nasser,2016) }\end{array}$ \\
\cline { 2 - 3 } & Equity ratio & $\begin{array}{l}\text { Equity ratio = equity / total assets (Rahman } \\
\text { et al., 2019) }\end{array}$ \\
\hline Firm size & Micro enterprises & $\begin{array}{l}\text { which sales are less than a million EGP } \\
(\text { www.cbe.com) }\end{array}$ \\
\cline { 2 - 3 } & Small enterprises & $\begin{array}{l}\text { which sales are between million EGP to 50 } \\
\text { million EGP (www.cbe.com) }\end{array}$ \\
\cline { 2 - 3 } & Medium enterprises & which sales are between 50 million EGP to \\
& 200 million EGP (www.cbe.com)
\end{tabular}

Firm age From The beginning of the Number of years of firm life firm's activity until now

\begin{tabular}{lll}
\hline $\begin{array}{l}\text { Firm } \\
\text { profitability }\end{array}$ & ROE & $\begin{array}{l}\text { ROE }=\text { net profit after taxes / equity } \\
(\text { Peterson and Schoeman, 2008) }\end{array}$ \\
\cline { 2 - 3 } & ROA & $\begin{array}{l}\text { ROA=net profit after taxes / total assets } \\
\text { (Peterson and Schoeman, 2008) }\end{array}$ \\
\cline { 2 - 3 } & NPM & $\begin{array}{l}\text { NPM = net profit after taxes / sales } \\
\text { (Delen and Demirkan,2013) }\end{array}$
\end{tabular}

\subsection{Data and Sampling}

The study depends on historical secondary data in order to measure the impact of capital structure on the profitability of MSMEs in Egypt. The data used in this study is extracted from the annual reports of 360 MSMEs in Egypt in the period from 2016 to 2019. The population size in this research is about 3.65 million companies in 2018/2019, according to data from the Central Agency for Public Mobilization and Statistics (www.capmas.gov.eg). The research sample was collected from 4 commercial banks operating in the banking sector in Egypt. 


\section{Findings}

The Correlation coefficient between Debt ratio and ROE, ROA and NPM in the Micro firm group.

\begin{tabular}{lll}
\hline & & Debt ratio \\
\hline \multirow{2}{*}{ ROE } & Spearman Correlation & $-0.537^{* *}$ \\
& Sig. & 0.0001 \\
\hline \multirow{2}{*}{ ROA } & Spearman Correlation & $-0.586^{* *}$ \\
& Sig. & 0.0001 \\
\hline \multirow{2}{*}{ NPM } & Spearman Correlation & $-0.389^{* *}$ \\
& Sig. & 0.0001 \\
\hline
\end{tabular}

It was found that there was a significantly negative correlation between Debt ratio and ROE, ROA and NPM, where micro firms $(\mathrm{P}<0.01)$. The reason may be that bank interest reduces net profit.

The Correlation coefficient between Debt ratio and ROE, ROA and NPM in the small firms group.

\begin{tabular}{lll}
\hline & & Debt ratio \\
\hline \multirow{2}{*}{ ROE } & Spearman Correlation & $-0.353^{*}$ \\
& Sig. & 0.003 \\
\hline \multirow{2}{*}{ ROA } & Spearman Correlation & $-0.251^{* *}$ \\
& Sig. & 0.027 \\
\hline \multirow{2}{*}{ NPM } & Spearman Correlation & $-0.357^{* *}$ \\
& Sig. & 0.002 \\
\hline
\end{tabular}

It was found that there was a moderately significant negative correlation between Debt ratio and ROE, ROA and NPM, where small firms $(\mathrm{P}<0.01)$. The reason may be that bank interest reduces net profit.

The Correlation coefficient between Debt ratio and ROE, ROA and NPM in the medium firms group.

\begin{tabular}{lll}
\hline & & Debt ratio \\
\hline \multirow{2}{*}{ ROE } & Spearman Correlation & $0.265^{* *}$ \\
& Sig. & 0.001 \\
\hline \multirow{2}{*}{ ROA } & Spearman Correlation & $0.269^{* *}$ \\
& Sig. & 0.001 \\
\hline \multirow{2}{*}{ NPM } & Spearman Correlation & $0.243^{* *}$ \\
& Sig. & 0.005 \\
\hline
\end{tabular}


It was found that there was a significantly positive correlation between debt ratio and ROE, ROA and NPM. Where medium firms (P value greater than 0.01 ). The reason may be that medium firms are able to afford the cost of finance when compared with micro and small enterprises, in addition to having a good assets turnover rate that is reflected in the revenues.

Regression Model of debt ratio as a dependent variable and ROE, ROA and NPM Coefficients

\begin{tabular}{|c|c|c|c|c|c|c|}
\hline \multirow{2}{*}{\multicolumn{2}{|c|}{ Model }} & \multicolumn{2}{|c|}{$\begin{array}{l}\text { Unstandardized } \\
\text { Coefficients }\end{array}$} & \multirow{2}{*}{$\begin{array}{l}\text { Standardized } \\
\text { Coefficients } \\
\text { Beta }\end{array}$} & \multirow[t]{2}{*}{$\mathrm{T}$} & \multirow[t]{2}{*}{ Sig. } \\
\hline & & B & Std. Error & & & \\
\hline \multirow{4}{*}{1} & (Constant) & 48.531 & 1.277 & & 38.009 & .0001 \\
\hline & ROE & .469 & .062 & .417 & 7.516 & .0001 \\
\hline & ROA & -.984 & .076 & -.753 & -12.994 & .0001 \\
\hline & NPM & -.074 & .085 & -.025 & -.871 & .384 \\
\hline
\end{tabular}

The corresponding $\mathrm{P}$ value of the model was 0.0001 . The results concluded that there was a significant impact of debt ratio on ROE and ROA, yet it was not significant with NPM. These results fulfill the $\mathrm{H} 1$ and $\mathrm{H} 2$ hypotheses for small and micro enterprises and do not fulfill so for medium enterprises. Interestingly enough, $\mathrm{H} 3$ for small, micro and medium enterprises was not supported.

Correlation coefficient between equity ratio and ROE, ROA and NPM in the micro firms group.

\begin{tabular}{lll}
\hline & & Equity ratio \\
\hline \multirow{2}{*}{ ROE } & Spearman Correlation & $0.537^{* *}$ \\
& Sig. & 0.0001 \\
\hline \multirow{2}{*}{ ROA } & Spearman Correlation & $0.586^{* *}$ \\
& Sig. & 0.0001 \\
\hline \multirow{2}{*}{ NPM } & Spearman Correlation & $0.389^{* *}$ \\
& Sig. & 0.0001 \\
\hline
\end{tabular}

It was found that there was a highly significant positive correlation between Equity ratio and ROE, ROA and NPM $(\mathrm{P}<0.01)$.

Correlation coefficient between equity ratio and ROE, ROA and NPM in the small firms group.

\begin{tabular}{lll}
\hline & & Equity ratio \\
\hline \multirow{2}{*}{ ROE } & Spearman Correlation & $0.353^{*}$ \\
& Sig. & 0.003 \\
\hline \multirow{2}{*}{ ROA } & Spearman Correlation & $0.251^{*}$ \\
& Sig. & 0.007 \\
\hline \multirow{2}{*}{ NPM } & Spearman Correlation & $0.257^{*}$ \\
& Sig. & 0.009 \\
\hline
\end{tabular}


It was found that there was a highly significant positive correlation between Equity ratio and ROE, ROA and NPM, (P <0.01) in the small firm samples. Micro and small enterprises that are able to use equity to achieve turnover experience a better reflection in revenue than debt ratio. This is due to the lower cost of equity compared to the cost of debt

Correlation coefficient between equity ratio and ROE, ROA and NPM in the medium firms group.

\begin{tabular}{lll}
\hline & & Equity ratio \\
\hline \multirow{2}{*}{ ROE } & Spearman Correlation & $-0.263^{*}$ \\
& Sig. & 0.001 \\
\hline \multirow{2}{*}{ ROA } & Spearman Correlation & $-0.273^{* *}$ \\
& Sig. & 0.001 \\
\hline \multirow{2}{*}{ NPM } & Spearman Correlation & $-0.338^{*}$ \\
& Sig. & 0.001 \\
\hline
\end{tabular}

It was found that there was a negative significant correlation. This outcome indicates that medium firms are able to use the debt ratio to achieve turnover which is better reflected in revenue than equity

Regression Model of Equity ratio as a dependent variable, ROE, ROA and NPM.

Coefficients

\begin{tabular}{|c|c|c|c|c|c|c|}
\hline \multirow{2}{*}{\multicolumn{2}{|c|}{ Model }} & \multicolumn{2}{|c|}{$\begin{array}{l}\text { Unstandardized } \\
\text { Coefficients }\end{array}$} & \multirow{2}{*}{$\begin{array}{l}\text { Standardized } \\
\text { Coefficients } \\
\text { Beta }\end{array}$} & \multirow[t]{2}{*}{$\mathbf{T}$} & \multirow[t]{2}{*}{ Sig. } \\
\hline & & B & Std. Error & & & \\
\hline \multirow{4}{*}{1} & (Constant) & 51.545 & 1.277 & & 40.349 & .0001 \\
\hline & ROE & -.469 & .062 & -.417 & -7.512 & .0001 \\
\hline & ROA & .984 & .076 & .753 & 12.985 & .0001 \\
\hline & NPM & .073 & .085 & .025 & .855 & .393 \\
\hline
\end{tabular}

The corresponding $\mathrm{P}$ value of the model being 0.0001 . These results showed that there was a significant impact of Equity ratio on ROE, ROA, and a lack of significance in regards to NPM. These results fulfill the $\mathrm{H} 4$ and $\mathrm{H} 5$ hypotheses for small and micro enterprises; yet do not fulfill so for medium enterprises. However, H6 for small, micro and medium enterprises is not supported.

\section{Conclusion}

The predominant objective of this research is to measure the impact of capital structure on the profitability of Egyptian MSMEs. In addition, this study explains the policies and mechanisms which are essential in supporting MSMEs, and improving their profitability. Furthermore, this study is keen on clarifying the optimal capital structure of Egyptian MSMEs; where MSMEs suffer from an array of problems.

Concerning micro samples and small samples, it was observed that there was a significantly 
negative correlation between Debt ratio and ROE, ROA and NPM. Conversely, it was found that there was a highly significant positive correlation between Equity ratio and ROE, ROA and NPM. This result tends to affirm the pecking order theory of micro and small businesses capital structure in Egypt; which states that internal sources of finance are better than external sources in the case of high interest rates due to the high costs of financing.

In regards to medium firms, it was deduced that there was a significantly positive correlation between debt ratio and ROE, ROA and NPM. On the other hand, it was found that there was a significantly negative correlation between Equity ratio and ROE, ROA and NPM. This result tends to support the tradeoff theory of Medium businesses capital structure in Egypt. Regarding firm age, it was found that smaller aged firms owned better rates of profitability than greater aged ones. Regarding firm size, it was found that smaller sized firms owned better rates of profitability than greater sized ones. However, these results do not fulfill the H8 hypothesis for all samples.

Therefore, it is indispensable for small and micro businesses to have a financial manager. Financial management is implemented to help businesses utilize bank financing for a specific purpose. In order to achieve positive effects of debt financing, banking finance ought to help the assets turnover so as to increase net profit. Micro and Small businesses should also have the necessary awareness about the use of short-term financing for short-term investments. They should also deploy long-term funds for long-term investments. Furthermore, businesses should make use of financing for their desired specific purposes when taking the loan; and not for merely any insignificant purposes.

Small and micro businesses cannot afford the costs of debt financing at the normal price. Normal pricing of bank loans can negatively affect Micro and small businesses. This highlights the vitality of the initiative of the Central Bank of Egypt which was launched in January of 2016; and proclaimed an interest rate of $5 \%$ to be set for small businesses. The central bank of Egypt ought to consider banks' commissions on transactions of micro and small businesses, in addition to launching an initiative specifically for micro businesses at a low debt interest rate.

Thus, the aforementioned results represent a huge opportunity for entrepreneurs; where the optimal capital structure is hereby determined for them. Commercial banks ought to take advantage of the results of this study related to medium businesses by means of illuminating the importance of bank financing for medium businesses; and consequently, financing them.

More importantly, the government ought to support micro and small enterprises. It should do so via offering tax reductions and guaranteeing benefits to micro and small enterprises. The government should also provide procedural advantages for the industrial cities of micro and small entities; in terms of the processes of obtaining land or the extraction of licenses. The Chambers of Commerce and MSMEs must provide training programs for MSMEs related to capital management, human capital management, and the extraction of export cards. In addition, training programs could also inform businesses about customs procedures and international trade agreements. Lastly, the government ought to set up a database that includes the profiles and number of MSMEs in Egypt. 


\section{Research Contribution}

There is no doubt that this research is of considerable usefulness for MSMEs, decision makers and basically any individual who happens to be interested in MSMEs. This is mainly due to its role in facilitating the impact of capital structure on the profitability of Egyptian MSMEs, as well as understanding the roles of firm size and firm age as controllers regarding this effect. This research also clarifies the optimal capital structure of Egyptian MSMEs in an effort to create insight and gather information so as to support practitioners in deciding on the best ways to finance their businesses.

The findings and conclusions have reached are considered of great importance to the following entities: Commercial banks, The Central bank of Egypt, small and medium business owners. As far as the central bank of Egypt is concerned, it should offer more support and launch more low-interest initiatives in an effort to help small and micro businesses, all the while collectively cutting down on initiatives for medium businesses in light of their ability to afford financing costs.

Concerning commercial banks, it is highly recommended that they make adequate use of the opportunities to offer more financing options for medium businesses owing to the ability of medium businesses to afford resorting to and utilizing bank financing even at high interest rates. Finally, in regards to micro, small and medium business owners; it is advisable that owners make formidable use of the findings and results of this study while deciding on the optimum means of financing befitting each category of business. For this shall greatly revitalize and amplify net profit and increase income ratings.

\section{Research Limitations}

Naturally, there are some limitations to this study which prevented generalizing the findings. For instance, the type of data used is historical time series data. Therefore, it may be affected by a certain event or policy that took place at the time of collecting said data. Historical Time series or panel data would be better off used in future research. Moreover, this study is limited to MSMEs in Egypt during the period from 2016 to 2019. The results cannot be generalized to other countries. In addition, due to the time constraint, the sample is only restricted to 360 MSMEs during the period from 2016 to 2019. Future research could increase the sample by allowing more time to collect data. Data was collected from only 4 banks; thus future research could increase the number of banks as sources of data. Over the course of this research, profitability is measured by NPM, ROA and ROE. Future research could increase the profitability measurements. In this research, firm age and firm size are utilized as the controlling variables. Future research could increase the controlling variables such as: MSMEs characteristics or level of a country's progress.

\section{References}

Abrar, \& Javaid. (2016). The Impact of Capital Structure on the Profitability of Microfinance Institutions. South Asian Journal of Management Sciences, 10(1), 21-37.

Ashraf, Ameen, \& Kiran. (2017). The Impact of Capital Structure on Firm's Profitability. 
International Journal of Business and Social Science, 8(4).

Aziz, \& Taher. (2017). The Impact of Capital Structure on the Firm's Profitability. International Journal of Economics, Commerce and Management, V(4).

Elasrag. (2012). The developmental role of SMEs in the Arab countries. MPRA Journal, Paper No. 40608.

Emin. (2016). Capital Structure and Firm Performance. Marmara University Journal, 15-30. https://doi.org/10.14780/iibd.81334

Housni, Hachimi, \& Salahddine. (2017). SME Financing in Morocco: Issues and Alternatives. Journal of Innovation \& Business Best Practice, 2017.

Jaskaran, \& Singh. (2014). Problems Related to the Financing of Small Firms in India. International Journal of Innovative Research \& Development, 3(1).

Javalgi, \& Todd. (2011). Entrepreneurial orientation, management commitment, and human capital: The internationalization of SMEs in India. Journal of Business Research, 64(9), 1004-1010. https://doi.org/10.1016/j.jbusres.2010.11.024

Jill. (2012). Growth plans of small business in India: individual Influences. Int. J. Entrepreneurship and Small Business Journal, 16(1).

Kale, Banwait, \& Laroiya. (2010). Performance evaluation of ERP implementation in Indian SMEs. Emerald Insight Journal, (1741).

Luka, \& Badmus. (2014, January). Capital Structure and Profitability of Nigerian Quoted Firms. American International Journal of Social Science, 3(1).

Moudine, \& El Khattab. (2016). Banking financing and credit risk: Case of the SMEs segment in Morocco. MPRA Paper No. 92686.

Mouhallab, \& Jianguo. (2016). Small and medium Enterprises in Morocco: Definition's Issues and Challenges. Research Gate Publication no. 307512387.

Naim. (2016). Effect of Capital Structure on Firm Profitability. Global Journal of Management and Business Research, 16(4).

Nasser. (2016). The impact of capital structure on Financial performance. BSFA.

Sadiq, \& Sher. (2016). The impact of Capital Structure on the Profitability. Global Journal of Management and Business, 16(1).

Safari, Emadi, Reza, \& Saadati. (2013). The Impact of Capital Structure on Firm Performance. Australian Journal of Basic and Applied Sciences, 7(4), 1-8.

Salawu. (2009). Impact of Capital Structure on Firms Profitability. The International Journal of Business and Finance Research, 3(2).

Sessa, Rami, Sandri, \& Ayadi. (2017). MSMEs Development in Egypt, Jordan, Morocco and Tunisia. Mediterranean Countries Journal, (3). 


\section{Macrothink \\ International Journal of Accounting and Financial Reporting ISSN 2162-3082 2021, Vol. 11, No. 1}

Singh, \& Wasadani. (2016). Finance for Micro, Small, and Medium-Sized Enterprises in India. $A D B$ institute, paper no. 525.

Verma, et al.. (2017). What constitutes financing gap in Indian SMEs - owners' perspective?. Emerald Insight Journal.

Zakaria, Zein, Othman, \& Yangand Jansen. (2013). SMEs experience in India. SMEs unit publication, EBI.

Ziky, \& Daouah. (2019). Exploring Small and Medium Enterprises' Perceptions towards Islamic Banking Products in Morocco. International Journal of Economics and Finance, 11(10).

\section{Copyright Disclaimer}

Copyright for this article is retained by the author(s), with first publication rights granted to the journal.

This is an open-access article distributed under the terms and conditions of the Creative Commons Attribution license (http://creativecommons.org/licenses/by/4.0/) 